\title{
Sistem Informasi Pengukuran Kinerja Pada Perkebunan Kelapa Sawit Dengan Menggunakan Metode Balanced Scorecard
}

\author{
Rosmiati $^{\mathrm{a}^{*}}$, Mustafid $^{\mathrm{b}}$, Ibnu Widiyanto $^{\mathrm{c}}$ \\ ${ }^{a}$ Mahasiswa Magister Sistem Informasi, Universitas Diponegoro \\ ${ }^{\mathrm{b} J u r u s a n}$ Statistik, Fakultas Sains dan Matematika, Universitas Diponegoro \\ 'Jurusan Manajemen, Fakultas Ekonomika dan Bisnis, Universitas Diponegoro
}

Naskah Diterima : 10 Oktober 2014; Diterima Publikasi : 20 Maret 2015

\begin{abstract}
Abstrak
Perkebunan kelapa sawit merupakan salah satu tanaman sub-sektor pertanian di Indonesia, yang merupakan sumber utama pangan dan pertumbuhan ekonomis. Balanced Scorecard (BSC) menjadi sebuah model sistem pengukuran kinerja yang dapat memberikan solusi dalam kerangka pengukuran kinerja terintegrasi dengan menggunakan aspek finansial maupun non finansial. Penelitian ini bertujuan untuk membangun sistem informasi untuk mengukur kinerja perkebunan kelapa sawit menggunakan metode Balanced Scorecard. Pengukuran kinerja menggunakan 4 perspektif, yaitu: pelanggan, keuangan, proses bisnis internal serta pertumbuhan dan pembelajaran. 9 indikator yang digunakan, yaitu: nilai kepuasan karyawan, nilai loyalitas karyawan, Return on Asset (ROA), solvabilitas, pemeliharaan tanaman, panen TBS, meningkatkan kompetensi mandor dan administrasi di lingkungan kebun, pengarahan manager kebun kepada karyawan dan menyediakan anggaran khusus untuk pelatihan. Penelitian ini menghasilkan suatu sistem informasi yang dapat menentukan bobot indikator dan skor penilaian kinerja selanjutnya akan diketahui pencapaian pengukuran kinerja pada perkebunan kelapa sawit. Penelitian ini dilakukan pada perkebunan Bina Karya, didapatkan kinerja yang cenderung stabil dari tahun 2009 sampai 2013. Pada tahun 2011 diperoleh nilai kinerja tertinggi sebesar $68.34 \%$ dan yang terendah pada tahun 2009 sebesar $60.84 \mathrm{~s} \%$.
\end{abstract}

Kata kunci: Pengukuran kinerja; Balance Scorecard; Key Performance Indicator; Sistem informasi; Kelapa sawit

\begin{abstract}
Palm oil plantations is one of the sub-sectors of agriculture crops in Indonesia, which is the main source of food and economic growth. The Balanced Scorecard (BSC) into a model of performance measurement system that can provide a solution within the framework of an integrated performance measurement using financial and non financial aspects. This study aims to develop information systems to measure the performance of oil palm plantations using the Balanced Scorecard method. Measurement of performance using four perspectives, that is: financial, customer, internal business processes and learning and growth. Nine indicators were used, that is: value of employee satisfaction, employee loyalty value, Return on Assets (ROA), solvency, crop maintenance, harvesting TBS, increasing the foreman and administrative competence in the garden, orchard manager guidance to employees and provide a special budget for training. This study resulted in an information system that can determine the weights of indicators and performance assessment scores will then be known to the achievement of performance measurement in oil palm plantations. This study was carried out on the Bina Karya plantation, obtained performance tends to be stable from 2009 to 2013. In 2011 the highest performance values obtained at $68.34 \%$ and the lowest was in 2009 at $60.84 \%$.
\end{abstract}

Keywords: Performance measurement; Balanced scorecard; Key Performance Indicator; Information system; Palm oil

\section{Pendahuluan}

Dalam perekonomian Indonesia, sektor pertanian dikenal sebagai sektor penting yang berperan sebagai sumber utama pangan dan pertumbuhan ekonomi. (Suryana et al., 2005). Perkebunan merupakan salah satu sub-sektor yang memberikan kontribusi pada sektor pertanian di Indonesia. Kelapa sawit merupakan salah satu tanaman perkebunan yang mempunyai peran penting bagi peningkatan pendapatan petani dan masyarakat. Industri kelapa sawit di Sumatera dan Kalimantan memiliki tingkatan pesat sejak tahun 1980, tapi tidak dikembangkan menjadi sistem agrobisnis yang kuat (Pahan, 2010).

Sistem informasi sangat berperan penting bagi organisasi dalam melakukan pengelolaan data, memproses dalam pengambilan keputusan untuk

*) Penulis Korespondensi: fayadhah@gmail.com 
mencapai tujuan organisasi (Kenneth dan Jane, 2007). Dalam beberapa dekade banyak perusahaan sukses dalam menghasilkan informasi pengukuran kinerja untuk pengembangan bisnisnya (Sai dan Tanweer, 2007). Pengukuran kinerja merupakan hal yang esensial bagi organisasi yang ingin tetap unggul dan bersaing didalam dunia bisnis. Pengukuran kinerja digunakan untuk membandingkan antara hasil dengan strategi organisasi yang dapat membantu dalam merencanakan strategi masa depan untuk mencapai target akhir organisasi (Wu et al.,, 2012). Selain itu, tujuan utama dari pengukuran kinerja adalah untuk memberikan informasi yang handal prosedur pengambilan keputusan (Aljardali et al., 2012).

Salah satu bentuk penilaian kinerja perusahaan adalah dengan menggunakan Balanced Scorecard. Balanced Scorecard (BSC) menjadi sebuah model sistem pengukuran kinerja yang paling populer dewasa ini yang menyediakan kerangka komprehensif serta menjadi sebuah solusi yang baik dalam kerangka pengukuran kinerja yang terintegrasi dengan menggunakan aspek finansial maupun non finansial (Lee et al., 2008). Beberapa penelitian mengenai pengukuran kinerja yang telah dilakukan antara lain adalah : pengukuran performance indeks kondisi kinerja pada universitas dengan BSC digunakan untuk peningkatan kualitas dan upaya perbaikan yang efisien ( $\mathrm{Wu}$ et al., 2011), pengukuran kinerja sebagai alat pengambil keputusan bagi manajer senior dengan menggabungkan antara metode SCM dan BSC (Bhagwat dan Sharma, 2007), pengukuran kinerja perusahaan dengan menggunakan 6 perspektif antara lain sistem dinamis, riset operasi atau teknologi informasi, logistik, pemasaran, organisasi dan strategi (Otto dan Kotzab, 2003), pengukuran kinerja rantai pasok berbasis kartu skor dan web portal menggunakan BSC (Nenad et al., 2011) dan penilaian kinerja pada laboratorium forensic untuk meningkatkan ilmu pengetahuan dan layanan dengan BSC (Houck et al., 2012).

\section{Kerangka Teori}

\subsection{Balanced Scorecard}

Kaplan dan Norton (2000) mengemukakan, Balanced Scorecard (BSC) merupakan suatu kerangka kerja untuk mengintegrasikan berbagai ukuran yang diturunkan dari strategi perusahaan, yaitu ukuran kinerja finansial masa lalu dan memperkenalkan pendorong kinerja finansial masa depan, yang meliputi perspektif pelanggan, proses bisnis internal, dan pembelajaran serta pertumbuhan, diturunkan dari proses penerjemahan strategi perusahaan yang dilaksanakan secara eksplisit dan ketat ke dalam berbagai tujuan dan ukuran yang nyata.

BSC terdiri dari dua kata, kartu skor (scorecard) dan berimbang (balance). Kartu skor adalah kartu yang digunakan untuk mencatat skor hasil kinerja seseorang, kartu skor juga dapat digunakan untuk merencanakan skor yang hendak diwujudkan oleh seseorang di masa depan. Melalui kartu skor, skor yang hendak diwujudkan di masa depan dibandingkan hasilnya dengan hasil kinerja sesungguhnya. Hasil perbandingan ini digunakan untuk melakukan evaluasi terhadap kinerja personel yang bersangkutan. Tujuan dan pengukuran BSC bukan hanya penggabungan dari ukuran keuangan dan non keuangan melainkan merupakan hasil dari suatu proses atas bawah (top-down) berdasarkan misi dan strategi dari suatu unit usaha. Sebagai salah satu alat pengukuran kinerja yang dapat memberikan gambaran menyeluruh, BSC tampil lebih sistematis sehingga kinerja yang terukur pun lebih terinci dengan empat perspektif yang digambarkan pada Gambar 1.

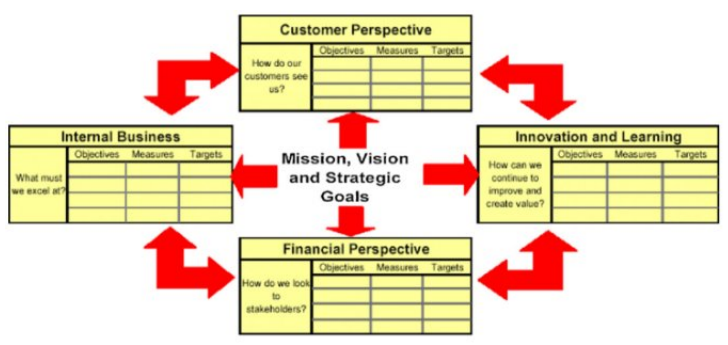

Gambar 1. Perspektif Balanced Scorecard (Chytas, 2011).

Metode BSC merupakan metode pengukuran kinerja yang terintegrasi dan mencakup keseluruhan aspek finansial dan non finansial. Dengan kata lain metode BSC merupakan metode yang menerjemahkan visi, misi dan strategi perusahaan ke dalam seperangkat sasaran-sasaran strategis yang dirumuskan menggunakan empat perspektif (Mulyadi, 2001 dan Gaspersz, 2002) yaitu :

1. Perspektif Keuangan, fungsinya mengukur kemampulabaan dari nilai pasar (market value) diantara perusahaan-perusahaan lain.

2. Perspektif Pelanggan, fungsinya yaitu mengukur mutu pelayanan dan rendahnya biaya dibandingkan dengan perusahaan lain.

3. Perspektif Bisnis Internal, fungsinya yaitu mengukur efisiensi dan efektivitas dalam memproduksi barang dan jasa

4. Perspektif Pembelajaran dan Pertumbuhan, fungsinya mengukur kemampuan perusahaan untuk mengembangkan dan memanfaatkan sumber daya manusia sehingga tujuan strategik perusahaan dapat tercapai untuk waktu sekarang dan masa yang akan datang.

Dalam perkembangan BSC telah banyak membantu perusahaan untuk sukses mencapai tujuannya. BSC memiliki beberapa keunggulan yang tidak dimiliki sistem strategi manajemen tradisional. Strategi manajemen tradisional hanya mengukur kinerja organisasi keuangan saja dan lebih menitik beratkan pengukuran pada hal-hal yang bersifat tangible, namun perkembangan bisnis menuntut 
untuk mengubah pandangan bahwa hal-hal intengible juga berperan dalam kemajuan organisasi. BSC menjawab kebutuhan tersebut melalui sistem manajemen strategi kontemporer yang terdiri dari empat perspektif (Mulyadi, 2001).

Beberapa tahap dalam merancang BSC (Rangkuti, 2011) sebagai berikut :

1. Merumuskan visi, misi, nilai, tujuan dan strategi perusahaan. Tahap ini menjadi landasan utama dalam penentuan perspektif.

2. Menentukan perspektif. Perspektif yang dipilih harus dapat mencerminkan strategi perusahaan.

3. Merumuskan sasaran strategi (objectivies). Menerjemahkan strategi ke dalam setiap perspektif yang berupa sasaran strategi. Sasaran strategi tersebut harus dapat mendukung pencapaian visi, misi, nilai, tujuan perusahaan dan strategi perusahaan.

4. Menentukan ukuran strategi (measures). Sasaran strategis yang telah dirumuskan melalui strategi perlu ditetapkan ukuran pencapaiannya. Ada dua ukuran yang perlu direncanakan untuk mengukur keberhasilan pencapaian sasaran strategis, yaitu (1) ukuran hasil (outcome measure atau lag indicator) dan (2) ukuran pemacu kinerja (performance driver measure atau lead indicator).

5. Menentukan target. Target merupakan pernyataan kuantitatif kinerja yang hendak dicapai dalam kurun waktu tertentu di masa mendatang untuk mewujudkan sasaran strategis dalam setiap perspektif.

6. Merumuskan inisiatif strategis. Inisiatif strategis merupakan pelaksanaan program yang bersifat strategis untuk mewujudkan sasaran strategis pada setiap perspektif. Hal itu dirumuskan dengan membuat suatu pernyataan kualitatif berupa langkah besar yang akan dilaksanakan di masa depan dan yang akan membantu pencapaian target.

BSC diimplementasikan atau tepatnya diturunkan ke setiap level dalam perusahaan dan bahkan ke setiap individu agar perusahaan mendapatkan hasil kinerja yang berlipat ganda.

\subsection{Keunggulan Balanced Scorecard}

Balanced Scorecard memiliki beberapa keunggulan sebagai berikut (Mulyadi (2001) :

a. Komprehensif

Balanced Scorecard menekankan pengukuran kinerja tidak hanya aspek kuantitatif saja, tetapi juga aspek kualitatif. Keempat perspektif menyediakan keseimbangan antara pengukuran eksternal seperti laba, sedangkan pada ukuran internal seperti pengembangan produk baru.

b. Koheren

Balanced Scorecard mengharuskan personil untuk menentukan hubungan sebab akibat diantara berbagai sasaran yang dihasilkan dalam setiap perencanaan. Setiap sasaran yang ditetapkan dalam perspektif keuangan harus mempunyai hubungan kausal dengan sasaran keuangan baik secara langsung maupun tidak langsung.

c. Seimbang

Keseimbangan sasaran yang dihasilkan oleh sistem perencanaan penting untuk menghasilkan kinerja keuangan yang berjangka panjang.

d. Terukur

Keterukuran sasaran yang dihasilkan oleh sistem perencanaan menjanjikan ketercapaian berbagai sasaran yang dihasilkan oleh sistem tersebut..

Dalam pengukuran kinerja dengan menggunakan metode Balanced Scorecard, pengukuran kinerja dimulai dengan menetapkan strategi terlebih dahulu, sedangkan Six Sigma lebih fokus kepada proses dan pelanggan kunci sedangkan Performance Prism yang dimulai dengan identifikasi siapa saja stakeholder yang terlibat dalam perusahaan. Kelebihan penggunaan Balanced Scorecard adalah bahwa dengan pendekatan Balanced Scorecard berusaha untuk menterjemahkan misi dan strategi perusahaan kedalam tujuan-tujuan dan pengukuran-pengukuran yang dilihat dari empat perspektif yaitu keuangan, pelanggan, proses bisnis internal, pembelajaran dan pertumbuhan tersebut.

\subsection{Kelemahan Balanced Scorecard}

Balanced Scorecard merupakan perkembangan baru dalam suatu manajemen perusahaan yaitu sebagai sarana pengukuran kinerja yang telah dicapai, dan harus lkita sadari bahwa masih banyak permasalahan yang belum dapat dipecahkan dengan Balanced Scorecard, misalnya :

1. Balanced Scorecard belum dapat menetapkan secara tepat sistem kompensasi yang biasanya merupakan tindak lanjut dari hasil penilaian kinerja.

2. Bentuk organisasi yang cocok untuk perkembangan proses dalam organisasi. Empat perspektif dalam Balanced Scorecard merupakan indikator yang saling berpengaruh (hubungan sebab akibat), sehingga diperlukan suatu wadah struktur yang dapat memberikan umpan balik kepada semua.

3. Belum adanya standar ukuran yang baku terhadap hasil penilaian kinerja perusahaan dengan metode Balanced Scorecard.

\subsection{Key Performance Indicator (KPI)}

Key Performance Indikator (KPI) dapat diartikan sebagai indikator yang akan memberikan informasi sejauh mana kita telah berhasil mewujudkan sasaran strategis yang telah kita tetapkan. Dalam menyusun KPI baiknya harus menetapkan indikator kinerja yang jelas, spesifik dan terukur (measurable) (Parmenter,2011).

Penilaian kinerja berdasarkan KPI bertujuan untuk : 
1. Mengukur kesehatan dan kesejahteraan organisasi secara keseluruhan.

2. Memfokuskan pada aspek atau area dari suatu kinerja organisasi yang kritikal dan vital secara berkelanjutan dan mengacu pada kesuksesan di masa yang akan datang.

3. Mengukur suatu kesuksesan dalam area yang dianggap penting dan proses yang memperngaruhi customer, pekerja, shareholder dan stakeholderi.

4. Membangun total organisasi, individu departement dan individual team sangat penting bagi sebuah perusahaan atau organisasi untuk paling tidak mengidentifikasi KPInya.

Kunci untuk mengidentifikasi suatu KPI adalah :

1. Menganalisa atau mendefinisikan proses bisnis

2. Mengetahui dengan jelas goals (tujuan-tujuan) atau performansi yang diharapkan untuk proses bisnisnya.

3. Memiliki pengukuran kuantitatif dan kualitatif dari hasil dan perbandingan dengan goals nya.

4. Menginvestigasikan variasi dan mengambil proses-proses atau sumber daya untuk memperoleh tujuan-tujuan pendek.

Dalam organisasi nirlaba, organisasi semacam itu biasanya didirikan oleh para pendiri dengan suatu misi tertentu untuk melayani golongan masyarakat tertentu dengan jasa pelayanan tertentu pula. Pendorong dan motivasi utama adalah pencapaian kebutuhan pelanggan, sebagai perwujudaan misi pendiri, bahkan kalau perlu rela mengalami defisit dalam segi keuangan. Oleh karena itu, maka ukuran pertama yang perlu diperhatikan ialah perspektif pelanggan untuk mencapai misi organisasi.

Dari visi dan misi digunakan untuk menentukan sasaran atau tujuan strategi (objective) pada masingmasing perspektif kemudian dilanjutkan dengan penentuan KPI (Key Performance Indicator). Satu tujuan strategi diperbolehkan memiliki KPI lebih dari satu. KPI atau indikator kinerja diartikan sebagai ukuran atau indikator yang memberikan informasi sejauh mana tujuan startegi yang tercapai. Dalam penyusunan KPI sebaiknya menetapkan indikator kinerja yang jelas, spesifik dan terukur.

Perhitungan bobot dan skor Balanced Scorecard dapat dilakukan tanpa memberikan bobot untuk masing-masing indikator (Rangkuti, 2011). Caranya dengan menghitung banyaknya indikator dan menghitung bobot indikator.

Keterangan :

Bobot Indikator $=$ Nilai kepentingan KPI dalam mencapai sasaran strategi

Bobot $=$ Nilai kepentingan KPI total pada tiap perspektif, yang telah ditentukan oleh pihak manajemen.

Jumlah indikator $=$ Banyaknya butir KPI pada perspektif yang bersangkutan..
Skor indikator merupakan tingkatan nilai atau level pengukuran dari level 4 sampai 1 , skor untuk nilai $A$ $=4, \mathrm{~B}=3, \mathrm{C}=2, \mathrm{D}=1$ dan $\mathrm{E}=0$

Keterangan :

Skor Tertimbang Maksimum= Nilai kepentingan KPI per spektif yang telah dikallikan dengan nilai skor maks

Jumlah Indikator $\quad=\quad$ Jumlah butir KPI pada perspektif bersangkutan

Skor Indikator Minimum $=$ Tingkatan nilai atau level maksimum $=4$

Bobot Indikator $\quad=\quad$ Nilai kepentingan KPI tersebut dalam mencapai sasaran strategi

Perhitungan Interval kelas untuk menentukan pembagian kelas pada target.

Keterangan :

Interval kelas $=$ Nilai range dalam kelas tiap skornya

Nilai Target $=$ Nilai yang ingin dicapai

Nilai Minimum $=$ Nilai minimum dari nilai target

Skor indikator maksimum $=$ Tingkatan nilai atau level maksimum 4

Nilai interval kelas untuk menentukan skor indikator masing-masing KPI. Hasil pengukuran atau realisasi masing-masing KPI terdiri dari nilai dan skor indikatornya.

Keterangan :

Skor Tertimbang $=$ Nilai kepentingan KPI tiap perspektif

Jumlah Skor Indikator = Jumlah skor indikator pada ke-4 perspektif

Bobot Indikator = Nilai kepentingan KPI

Perhitungan nilai akhir komponen, yaitu perhitungan kinerja pada masing-masing perspektif.

Keterangan:

Nilai Akhir Komponen $=$ Nilai $\quad$ kinerja $\quad$ yang didapatkan tiap perspektif

Skor Tertimbang $=$ Nilai kepentingan KPI tiap perspektif

Skor Tertimbang Maksimum = Nilai kepentingan KPI perspektif yang telah dikalikan dengan nilai skor maksimum.

Perhitungan nilai akhir total atau total skor merupakan penentuan nilai kinerja akhir.

Keterangan :

Nilai Akhir total (NA) $=$ Nilai Total hasil penilaian kinerja ke-4 perspektif

Jumlah Skor Tertimbang = Nilai kepentingan KPI tiap perspektif dalam pengukuran kinerja 
Jumlah Skor Tertimbang maksimum $=$ Nilai kepentingan KPI per perspektif yang telah dikalikan dengan nilai skor maksimum.

\section{Metodologi}

\subsection{Metode Penelitian}

Data yang digunakan dalam penelitian ini berkaitan dengan kinerja perkebunan kelapa sawit yang diperoleh dari data-data yang bersumber dari laporan-laporan yang berkaitan dengan perkebunan kelapa sawit. Data tersebut merupakan hasil dari kumpulan informasi yang berasal dari berbagai sumber dan dapat dipertanggungjawabkan secara ilmiah melalui wawancara dan dokumentasi. Untuk membangun sistem informasi pengukuran kinerja perkebunan kelapa sawit diperlukan alat berupa perangkat keras dengan spesifikasi sebagai berikut: Prosesor intel Core 2 Duo, Memori 2 GB, HDD 80 GB. Sedangkan perangkat lunak yang digunakan berupa dashboard yang memiliki spesifikasi berupa Sistem Operasi Windows 7, Database MySQL dan Bahasa pemrograman PHP.

\subsection{Pengukuran Kinerja}

Bobot menunjukkan nilai kepentingan perspektif pelanggan dalam penilaian kinerja perkebunan kelapa sawit yaitu sebesar 30\%. Target menunjukkan nilai yang ingin dicapai, untuk KPI nilai kepuasan pelanggan dan nilai loyalitas pelanggan didapatkan dari hasil kuesioner yang memiliki target nilai maksimal 4 karena pada kuesioner disediakan jawaban masing-masing pertanyaan ada 4 pilihan yaitu kurang puas, cukup puas, puas dan sangat puas dengan skor berturut-turut 1, 2, 3, dan 4 . Realisasinya merupakan hasil perhitungan sesuai dengan rumus masing-masing KPI.

Perspektif keuangan dalam penilaian kinerja perkebunan kelapa sawit sebesar 30\%. Target menunjukkan nilai yang ingin dicapai pada masingmasing KPI, besaran target pada perspektif keuangan diambil dari persentase hasil laporan keuangan pada perkebunan kelapa sawitBina Karya. KPI Return On Assets ditargetkan sebesar $15 \%$ artinya mengukur kemampuan perkebunan kelapa sawit dalam memperoleh hasil usaha.

KPI solvabiltas ditargetkan sebesar $15 \%$ artinya menunjukkan kemampuan perkebunan kelapa sawit untuk memenuhi kewajibannya. artinya mengukur perpsektif proses bisnis internal perkebunan kelapa sawit yang terdiri dari sasaran strategis, KPI, bobot dan target. Bobot menunjukkan nilai kepentingan perspektif proses bisnis internal dalam penilaian kinerja perkebunan kelapa sawit yaitu sebesar $20 \%$. Target menunjukkan nilai yang ingin dicapai, untuk KPI pemeliharaan tanaman ditargetkan $10 \%$ artinya mengukur keberhasilan dari TBS tersebut. KPI panen TBS ditargetkan 20\% artinya mengukur kemampuan dari produktifitas tersebut.
Perspektif pembelajaran dan pertumbuhan perkebunan kelapa sawit yang terdiri dari sasaran strategis, KPI, bobot dan target. Bobot menunjukkan nilai kepentingan perspektif pembelajaran dan pertumbuhan dalam pengukuran kinerja perkebunan kelapa sawit yaitu sebesar 20\%. Target menunjukkan nilai yang ingin dicapai, untuk KPI meningkatkan kompetensi mandor dan administrasi dilingkungan kebun ditargetkan sebanyak 5 kali artinya pelaksanaan untuk meningkatkan kompetensi karyawan, untuk KPI pengarahan manajer kepada karyawan ditargetkan 5 kali artinya memberikan motivasi pada karyawan, untuk KPI tersedianya anggaran khusus untuk pelatihan artinya ada ketersediaan anggaran khusus dan penyisihan dana.

\subsection{Prosedur Penelitian}

Agar penelitian yang dilakukan lebih terarah maka langkah-langkah yang dilakukan di dalam prosedur penelitian dimulai dengan mengidentifikasi masalah-masalah yang terdiri dari wawancara dan studi literatur. Kemudian penentuan KPI, melakulan analisa desain sistem dan membuat dashboard sistem informasi pengukuran kinerja perkebunan kelapa sawit. Langkah-langkah tersebut dapat terlihat seperti pada Gambar 2.

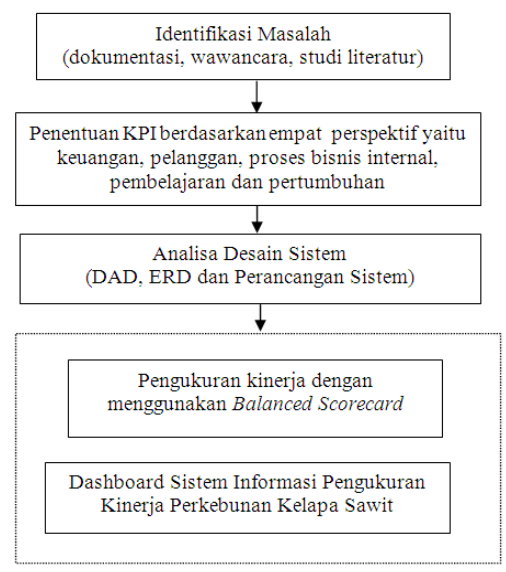

Gambar 2. Prosedur penelitian

\subsection{Perancangan Sistem}

Perancangan sistem informasi dengan Balanced Scorecard untuk pengukuran kinerja perkebunan kelapa sawit meliputi data flow diagram (DFD), entity relathionship diagram (ERD), relasi antar tabel, struktur tabel dan antarmuka. DFD untuk memodelkan sistem berdasarkan aliran data yang terdapat dalam sistem, DFD terdiri dari diagram konteks dan diagram rinci DFD (DFD leveled). Diagram konteks sistem terlihat pada Gambar 3. 


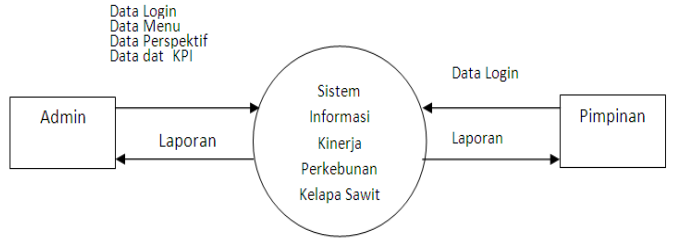

Gambar 3. Diagram konteks sistem

Sistem informasi pengukuran kinerja perkebunan kelapa sawit memiliki 2 pengguna yaitu : admin dan pimpinan.

a. Admin memiliki kewenangan menginputkan data antara lain data karyawan, nilai KPI dan mengatur menu. Admin dapat melihat laporan penilaian yang berupa tabel dan grafik dari keempat perspektif maupun penilaian total. Isi tabel terdiri dari daftar KPI, bobot, target, realisasi dan nilai, sedangkan grafik menggambarkan nilai capaian target dan realisais.

b. Pimpinan memiliki kewenangan melihat laporan penilaian seperti pada admin.

Dari diagram konteks diturunkan ke DFD level 1, untuk menggambarkan secara lebih rinci interaksi antara entitas dalam sistem dan databasenya dengan 4 proses yaitu:

a. Proses Login

Proses login merupakan prosedur utama untuk dapat mengakses halaman-halaman berikutnya. Setiap user yang terdiri dari admin dan pimpinan harus menginputkan data email dan passwordnya. Sistem melakukan pengecekkan untuk mencocokkan data yang ada.

b. Proses Admin

Proses admin merupakan kelanjutan dari proses login apabila penggunaannya sebagai admin. Proses admin melakukan penginputan data-data yaitu menu, perspektif, dan nilai KPI.

c. Proses Nilai KPI

Proses penilaian merupakan proses perhitungan untuk menentukan nilai kinerja perkebunan kelapa sawit, rumus-rumus yang digunakan dalam perhitungan sesuai dengan rumus yang telah dibahas sebelumnya. Data-data yang diproses diinputkan oleh admin.

d. Proses Laporan

Proses laporan merupakan proses menampilkan hasil perhitungan dari proses penilaian. Bentuk tampilanlaporan berupa tabel dari masing-masing perspektif maupun gabungan dari keempat perspektif yang dilengkapi dengan gambar grafik capaian realisasi dan target.

\subsection{Kerangka Sistem Informasi Pengukuran Kinerja Perkebunan Kelapa Sawit.}

Kerangka sistem yang akan dibangun seperti terlihat pada Gambar 4 Sistem Informasi pengukuran kinerja perkebunan kelapa sawit di dapat dari datadata input berupa: data keuangan, data pelanggan, data bisnis internal serta data pembelajaran dan pertumbuhan. Hasil dari pengukuran kinerja perkebunan kelapa sawit menghasilkan grafik pengukuran kinerja perkebunan kelapa sawit.

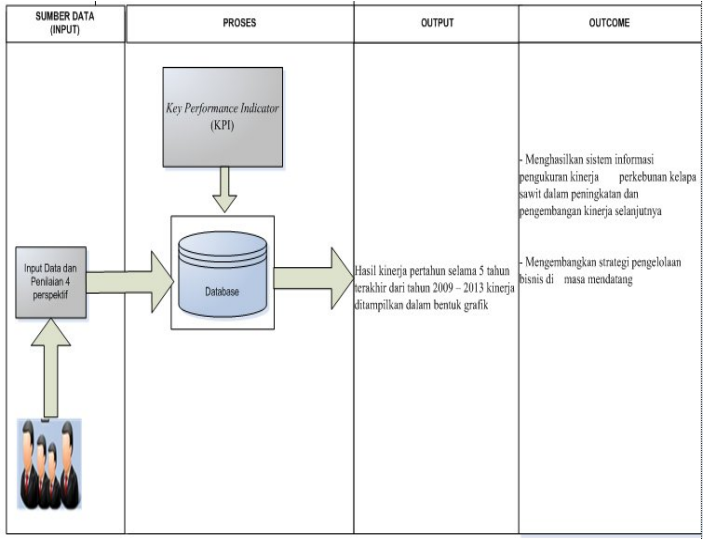

Gambar 4. Kerangka sistem informasi pengukuran kinerja

\section{Hasil dan Pembahasan}

\subsection{Hasil Penelitian}

Pada penelitian ini dihasilkan sebuah sistem informasi pengukuran kinerja dengan metode BSC, dengan inputan data rencana anggaran kerja, realisasi yang dikerjakan selama 5 tahun yang dibuat oleh admin dan pimpinan kebun. Data laporan realisasi keuangan selama 5 tahun, biaya pengadaan kebun kelapa sawit dan perlengkapannya, data panen dan keuangan, data kuesioner dan interview. Data-data tersebut digunakan untuk sistem informasi pengukuran kinerja perkebunan kelapa sawit dengan 4 perspektif dan 9 indikator.

\subsection{Sistem Informasi Pengukuran Kinerja Perkebunan Kelapa Sawit}

Sistem informasi merupakan hasil program aplikasi yang dibuat sesuai dengan perancangan yang telah dibuat. Apabila proses login berhasil, maka akan tampil form menu utama yang berisi menu Tambah Data, Data, Grafik dan Akses (Gambar 5).

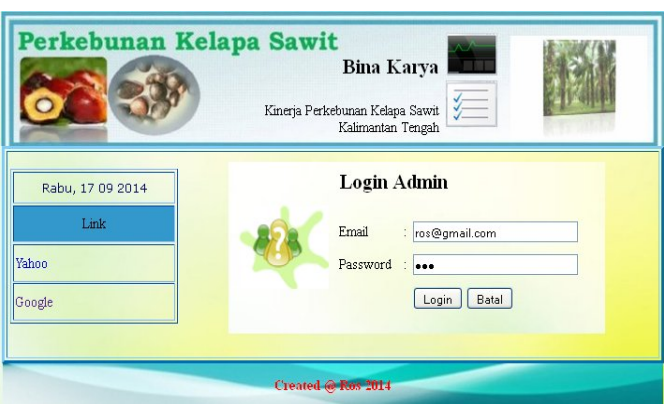

Gambar 5. Tampilan menu utama

Hasil perhitungan untuk tahun 2013 tertera pada Gambar 6 berikut ini. 


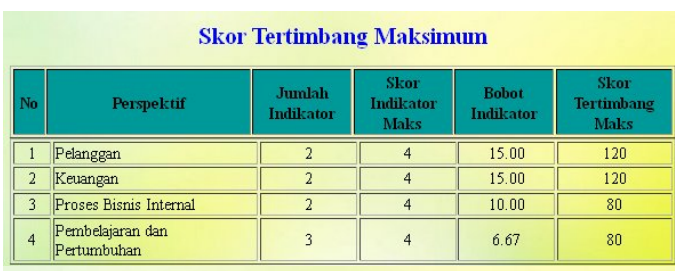

Jumlah Skor Indikator

Tahun : 2013

\begin{tabular}{|c|l|c|}
\hline No & \multicolumn{1}{|c|}{ Perspektif } & $\begin{array}{c}\text { Total Skor } \\
\text { Indikator }\end{array}$ \\
\hline \hline 1 & Pelanggan & 4 \\
\hline 2 & Keuangan & 6 \\
\hline 3 & Proses Bisnis Internal & 5 \\
\hline 4 & Pembelajaran dan Pertumbuhan & 9 \\
\hline
\end{tabular}

Nilai Akhir Komponen

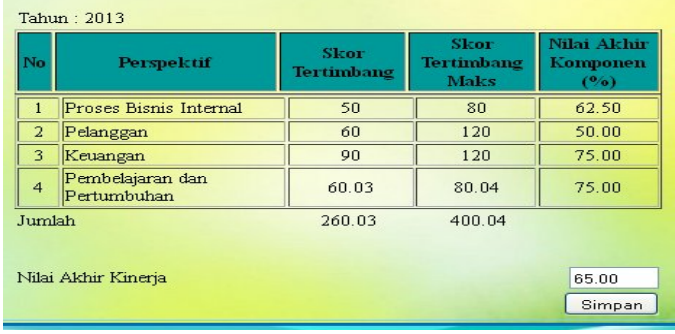

Nilai Akhir (NA) = Jumlah Skor Tertimbang/Jumlah Tertimbang $* 100$

Nilai Akhir $(\mathrm{NA})=260.03 / 400 * 100$

Nilai Akhir $(\mathrm{NA})=65.01$

Gambar 6. Hasil perhitungan Balanced Scorecard

Perhitungan tiap komponen selama 5 tahun dari tahun 2009-2013 dimana tiap-tiap perspektif akan dihitung skornya dan menghasilkan nilai komponen pada tahun 2009 perspektif pelanggan 50.00\%, perspektif keuangan $75.00 \%$, perspektif bisnis internal $50.00 \%$, perspektif pembelajaran dan pertumbuhan $66.70 \%$. Pada tahun 2010 perspektif pelanggan $50.00 \%$, perspektif finansial $62.50 \%$, perspektif bisnis internal $87.50 \%$ serta perspektif pertumbuhan dan pembelajaran $75.04 \%$.

Pada tahun 2011 perspektif pelanggan $50.00 \%$, perspektif finansial $75.00 \%$, perspektif proses bisnis internal $87.50 \%$ serta perspektif pembelajaran dan pertumbuhan $66.70 \%$. Di tahun 2012 perspektif pelanggan $50.00 \%$, perspektif finansial $75.00 \%$, perspektif proses bisnis internal $75.00 \%$ serta perspektif pembelajaran dan pertumbuhan $75.04 \%$. Terakhir di tahun 2013 perspektif pelanggan $50.00 \%$, perspektif finansial $75.00 \%$, perspektif proses bisnis internal $62.50 \%$ serta perspektif pertumbuhan dan pembelajaran 75.04. Grafik perkembangan ini tertera dalam Gambar 7 berikut ini.

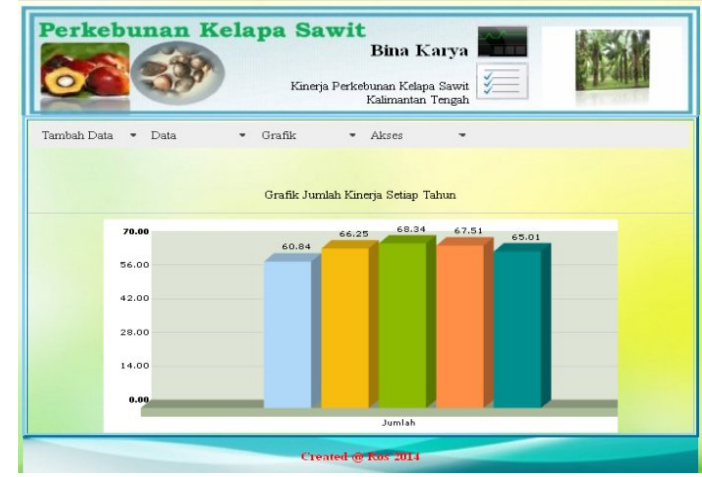

Gambar 7. Grafik hasil pengukuran kinerja

Gambar 7 menampilkan kesimpulan hasil pengukuran kinerja pada perkebunan kelapa sawit dalam 4 perspektif selama lima tahun, didapatkan nilai akhir sebesar 60.84 pada tahun $2009,66.26$ pada tahun 2010, 68.34 pada tahun 2011,67.51 pada tahun 2012, dan 65.01 pada tahun 2013.

\subsection{Pembahasan}

Rancangan Sistem Informasi dengan Balanced Scorecard untuk pengukuran kinerja dan merupakan aplikasi yang berbasis web dengan studi kasus pada perkebunan kelapa sawit. Penelitian ini menerapkan metode Balanced Scorecard. BSC adalah alat ukur untuk mengukur kualitas kinerja perkebunan kelapa sawit. Untuk menilai kinerja perkebunan kelapa sawit dengan analisa Balanced Scorecard meliputi empat perspektif yaitu perspektif pelanggan, perspektif keuangan, perspektif proses bisnis internal dan perspektif pembelajaran dan pertumbuhan. Keefektifan penilaian kinerja sangat tergantung dari penentuan indikator kinerja (key performance indikator - KPI), bobot dan target masing-masing perspektif yang disesuaikan dengan tujuan bisnis industri perkebunan.

Jumlah indikator kinerja dalam penelitian ini sebanyak 9 indikator. Perspektif pelanggan dengan 2 indikator kinerja yaitu nilai kepuasan dan nilai loyalitas pelanggan (dari hasil kuesioner). Perspektif finansial dengan 2 indikator kinerja yaitu Return on Assets (ROA) dan sovabilitas. Perspektif proses bisnis internal dengan 2 indikator kinerja yaitu penghematan pemeliharaan tanaman dan panen TBS (Tandan Buah Segar). Perspektif pembelajaran dan pertumbuhan dengan 3 indikator kinerja, yaitu meningkatkan kompetensi mandor dan administrasi, pengarahan manajer kebun kepada karyawan dan menyediakan anggaran untuk pelatihan.

Pengisian data target ke dalam sistem dilakukan oleh admin, hasil pengukuran kinerja perkebunan kelapa sawit ditampilkan dalam bentuk tabel penilaian dan grafik. Indikator keberhasilan kinerja 
ditampilkan dalam kesimpulan kondisi kinerja perkebunan kelapa sawit berdasarkan nilai akhir hasil perhitungan dari program aplikasi. Bobot dan target dapat berubah-ubah sesuai dengan keadaan kebutuhan dan keinginan perkebunan kelapa sawit.

\section{Kesimpulan}

Dari hasil penelitian dapat disimpulkan bahwa sistem informasi dengan metode Balanced Scorecard untuk pengukuran kinerja pada perkebunan kelapa sawit selama 5 tahun dari hasil nilai akhir komponen perspektif pelanggan menunjukan nilai komparasi cukup puas, keuangan sangat puas, proses bisnis internal sangat puas dan pembelajaran dan pertumbuhan sangat puas. Dan hasil nilai akhir kinerja pada tahun 2009 sebesar $60.84 \%$, pada tahun 2010 sebesar $66.26 \%$, pada tahun 2011 sebesar $68.34 \%$, pada tahun 2012 sebesar $67.51 \%$ dan pada tahun 2013 sebesar $65.01 \%$.

Studi kasus ini dilakukan pada perkebunan kelapa sawit dengan hasil kinerja yang cenderung meningkat dari tahun 2009 sampai 2013. Pada tahun 2011 diperoleh nilai kinerja tertinggi sebesar $68.34 \%$, dan yang terendah pada tahun 2009, sebesar $60.84 \%$ sebagaimana dapat dilihat dalam bentuk grafik.

\section{Daftar Pustaka}

Aljardali, H., Mazen Kaderi, M. and Tadjine, T.L., 2012. The implementation of the balanced scorecard in lebanese public higher education institutions, Procedia - Social and Behavioral Sciences, 62, $98-108$

Bhagwat, R., and Sharma, M.K., 2007. Performance measurement of supply chain management: A balanced scorecard approach, Computers\& Industrial Engineering, 53, 43-62.

Chytas, P., Glykasb, M., and Valiris, G., 2011. A Proactive balanced scorecard, International Journal of Information Management, 31, 460 468.

Gaspersz, V., 2002. Sistem Manajemen Kinerja Terintegrasi Balanced Scorecard dengan Six Sigma Untuk Organisasi Bisnis dan Pemerintah. PT. Gramedia Pustaka Utama.
Houck, M., Speaker, P.J., Fleming, A.S., dan Riley Jr, R.A, 2012. The Balanced Scorecard: Sustainable performance assessment for forensic laboratories, Science and Justice, 52, 209-216.

Kaplan, R. S., and Norton, David, P., 1992. The Balanced Scorecard Measures That Drive Perfomance, Harvard Business Review, JanuaryFebruary 1992, pp.71-79

Kaplan R.S., and Norton David, P., 2000. Balanced Scorecard, Menerapkan Strategi Menjadi Aksi, Erlangga, Jakarta.

Kenneth, C. L., and Jane, P. L., 2005. Management Informations System. Managing the Digital Firm,

Lee, A.H., Chen, W.C., and Chang, C.J., 2008. A fuzzy AHP and BSC approach for evaluating performance of IT department in the manufacturing industry in Taiwan, Expert Systems with Applications, 34, 96-107.

Mulyadi. 2001. Balanced Scorecard: Alat Manajemen Kontemporer untuk Pelipatganda Kinerja Perusahaan. Jakarta: Salemba empat.

Nenad, S., and Stefanovic, D., 2011. Supply Chain Performance Measurement System Based on Scorecards and Web Portals. ComSIS Vol. 168 8, No. 1, January 2011.

Otto, A., and Kotzab, H., 2003. Does supply chain management really pay? Six perspectives to measure the performance of managing a supply chain. European Journal of Operational Research 144 (2003) 306-320.

Pahan, I., 2010. Panduan lengkap kelapa sawit, Manajemen agribisnis dari hulu hingga hilir, Jakarta, Penebar Swadaya.

Parmenter, D, 2007. Developing, Implementing and Using Winning KPIs, John Wiley \& Sons.

Rangkuti, F., 2011, SWOT Balanced Scorecard, PT Gramedia Pustaka Utama, Jakarta.

Sai, N., and Tanweer, A., 2007. Performance measurement in the construction industry : An action case investigating manufactioring methodologist, 58(7), 667-676.

Suryana, A., Goenadi, D.H., Dradjat, B., Emingpraja, L., dan Hutabarat, B., 2005. Prospek dan Arah Pengembangan Agribisnis Kelapa Sawit. Jakarta : Badan Penelitian dan Pengembangan Pertanian, Departemen Pertanian. 